Research paper

\title{
Changes in ultrastructural features of the foraminifera Ammonia spp. in response to anoxic conditions: Field and laboratory observations
}

\author{
K.A. Koho ${ }^{\mathrm{a}, *}$, C. LeKieffre ${ }^{\mathrm{b}}$, H. Nomaki ${ }^{\mathrm{c}}$, I. Salonen ${ }^{\mathrm{a}}$, E. Geslin ${ }^{\mathrm{d}}$, G. Mabilleau ${ }^{\mathrm{e}}$, \\ L.H. Søgaard Jensen ${ }^{\mathrm{b}}$, G.-J. Reichart ${ }^{\mathrm{f}}$ \\ ${ }^{\text {a } U n i v e r s i t y ~ o f ~ H e l s i n k i, ~ D e p a r t m e n t ~ o f ~ E n v i r o n m e n t a l ~ S c i e n c e s, ~ V i i k i n k a a r i ~ 1, ~ H e l s i n k i, ~ F i n l a n d ~}$ \\ ${ }^{\mathrm{b}}$ Laboratory for Biological Geochemistry, School of Architecture, Civil and Environmental Engineering (ENAC), Ecole Polytechnique Fédérale de Lausanne (EPFL), \\ Switzerland \\ ' Japan Agency for Marine-Earth Science and Technology (JAMSTEC), 2-15 Natsushima-cho, Yokosuka, 237-0061, Japan \\ ${ }^{\mathrm{d}}$ UMR CNRS 6112 - LPG-BIAF, University of Angers, France \\ e Service commun d'imageries et d'analyses microscopiques (SCIAM), Institut de Biologie en Santé, University of Angers, France \\ ${ }_{\mathrm{f}}^{\mathrm{f}}$ Department of Ocean Systems, NIOZ-Royal Netherlands Institute for Sea Research and Utrecht University, Den Burg, The Netherlands
}

\section{A R T I C L E I N F O}

\section{Keywords:}

Benthic foraminifera

Anoxia

Ultrastructure

Lipid droplets

Bacteria

\begin{abstract}
A B S T R A C T
The ultrastructure of the living foraminiferan, Ammonia sp. (phylotype unknown), collected from surficial and deeper, subsurface (anoxic) sediments from the Dutch Wadden Sea, was examined to provide information on the physiology of the foraminiferal cell and its adaptive strategies to low-oxygen conditions. The observed changes in cell ultrastructure under anoxia were further compared with the cell ultrastructure of Ammonia sp. (phylotype T6), from oxic and anoxic incubation experiments. The ultrastructural evidence indicates that under low-oxygen conditions Ammonia spp. may accumulate lipid droplets. In addition, the size of the lipid droplets may increase with the duration of anoxic conditions, becoming over $5 \mu \mathrm{m}$ in size, while the remaining cytosol of the foraminiferan become less electron dense. In some specimens, lipid droplets were also found in the space between the plasma membrane and the organic lining. We expect that the apparent increase in the number and size of the lipid droplets is indicative of a stress response of the foraminifera to the adverse anoxic conditions. Other ultrastructural changes in response to anoxia include the presence of intact bacteria and electron dense opaque bodies within the foraminiferal cytosol, and a possible thickening of the organic lining. The role of the bacteria remains enigmatic but they may be linked to foraminiferal dormancy in anoxia.
\end{abstract}

\section{Introduction}

In shallow-water subtidal and intertidal areas, benthic foraminifera have been reported to occupy relatively irregular infaunal distributions with a number of living specimens found as deep as $35 \mathrm{~cm}$ below the sediment-water interface (Moodley and Hess, 1992). In addition, recent field studies applying the highly discriminate CellTracker Green fluorogenic probe technique have also shown that specimens of the foraminifera Ammonia tepida live well below the oxygen penetration depth in sediment, although the maximum abundances of $A$. tepida are always noted in the surficial sediments (Thibault De Chanvalon et al., 2015; Cesbron et al., 2016). Furthermore, experimental work by Nardelli et al. (2014) indicate that live individuals of $A$. tepida are able to withstand anoxic conditions and even calcify and grow in the absence of oxygen.

The survival mechanisms of shallow-water foraminifera, including
Ammonia spp., under anoxia are currently under debate and different coping strategies have been suggested. Anaerobic metabolism, namely denitrification via an intracellular nitrate pool, has been demonstrated for various species of benthic foraminifera (Risgaard-Petersen et al., 2006; Piña-Ochoa et al., 2010; Bernhard et al., 2012). However, it is currently not known whether denitrification is catalyzed by the foraminifera proper, or by potential endosymbionts of the foraminifera; evidence for both strategies exists (Risgaard-Petersen et al., 2006; Bernhard et al., 2012). The experimental work of Nomaki et al. (2014) supports survival under anoxia via denitrification, as Ammonia sp. (phylotype T6 of Holzmann, 2000 and Hayward et al., 2004; = Ammonia beccarii of Nomaki et al., 2014) was observed to incorporate ${ }^{15} \mathrm{~N}$ labeled nitrate into foraminiferal cytosol and subsequent ${ }^{15} \mathrm{~N}$-enrichments, suggesting nitrate utilization and a possible denitrification process in the cells exposed to anoxia. In contrast, under oxic incubations no isotope enrichment was seen, implying that, in the presence of

\footnotetext{
* Corresponding author.

E-mail address: karoliina.koho@helsinki.fi (K.A. Koho).
} 
oxygen, the foraminifera are not incorporating labeled nitrate. No denitrification rates have been measured for Ammonia spp., however, and only very low concentrations of intracellular nitrate pools have been observed for this genus (Piña-Ochoa et al., 2010; Geslin et al., 2014).

In addition to anaerobic respiration, a reduced metabolism and the potential dormancy of foraminifera have been suggested as coping mechanisms for shallow-water foraminifera living under low-oxygen conditions. For example, Bernhard and Alve (1996) measured low adenosine triphosphate (ATP) levels, implying reduced metabolic rates, in two species of foraminifera when incubated in anoxic conditions. In a study of Ammonia sp. (phylotype T6) by Nomaki et al. (2016), cells were observed to incorporate more ${ }^{15} \mathrm{~N}$-labeled nitrate and ${ }^{34} \mathrm{~S}$-labeled sulfate under dysoxic (in the study defined as $\mathrm{O}_{2}=0.1-22 \mu \mathrm{mol} 1^{-1}$ ) than anoxic conditions, indicating the reduced activity of foraminifera in anoxic conditions. Additionally, LeKieffre et al. (2017) have shown, using nanoSIMS analysis, that Ammonia sp. (phylotype T6, = Ammonia tepida of LeKieffre et al., 2017) decreases its metabolism and enters dormancy under anoxia. Dormancy or reduced metabolism could be a widespread response in benthic foraminifera to survive unfavorable conditions (e.g., anoxia) (Ross and Hallock, 2016). This coping mechanism could be especially common for shallow-water foraminifera living in dynamic environments, like subtidal and intertidal settings, which experience frequent changes in pore water chemistry associated with tidal action (e.g., Taillefert et al., 2007). In addition, these environments are commonly heavily bioturbated due to the relatively high abundance of macrofauna, leading to the potential development of oxygenated micro-niches deeper in the sediment (e.g., Aller and Aller, 1992; Wenzhöfer and Glud, 2004).

Ultrastructural analyses can provide insights for foraminiferal survival mechanisms in low-oxygen conditions. Presence of potential endosymbionts involved in denitrification or other biogeochemical functions, enabling foraminifera to survive anoxia, can be detected and visualized. Many species of benthic foraminifera, which inhabit low-oxygen environments, seem to possess various potential endosymbionts (e.g., Bernhard, 1993; Bernhard, 1996; Bernhard, 2003; Bernhard et al., 2012; Tsuchiya et al., 2015; Bernhard et al., 2017). Extensive peroxisomes complexed with endoplasmic reticulum, which are atypical in foraminifera from aerated habitats, have also been linked to foraminiferal survival in low-oxygen and chemocline sediments (e.g., Nyholm and Nyholm 1975, Bernhard, 1996, Bernhard and Bowser, 2008). Peroxisomes are known to have diverse biogeochemical functions, including oxidative reactions producing hydrogen peroxide that is metabolized to oxygen and water, thus, potential benefitting foraminifera in hostile anoxic conditions (Bernhard, 1996 and references therein). Other distinct ultrastructural features linked to foraminifera and low-oxygen environments include reduced numbers of mitochondria, or distinct organization of mitochondria along the periphery of foraminiferal chambers and associated test pores (Bernhard, 1996 and references therein). The close proximity of mitochondria to pore spaces may be related to enhanced gas exchange.

In this paper, we have compiled the ultrastructural features of Ammonia sp. (phylotype T6) and Ammonia sp. (phylotype unknown, Schweizer et al., 2011) from natural sediment layers, as well as from experimentally induced oxic and anoxic sediments. The ultrastructure of the specimens from contrasting redox environments were inspected in detail, providing essential clues about the physiology of the foraminifera, and hence their adaptive strategies to specific environments (e.g., Bernhard, 2003; Bernhard and Bowser, 2008).

\section{Methods}

\subsection{Field study}

Intact sediment cores were sampled by hand from the Dutch Wadden Sea tidal mudflat (Mokbaai, Texel), during the low tide in August 2015 and February 2016. The cores were immediately transported to the nearby laboratory of the Royal Netherlands Institute for Sea Research (Royal NIOZ), which is located $<5 \mathrm{~km}$ from the sampling site. In the acclimatized laboratory (set at $15{ }^{\circ} \mathrm{C}$ in August and $12{ }^{\circ} \mathrm{C}$ in February), the cores were processed for pore water chemistry, including dissolved oxygen $\left(\mathrm{O}_{2}\right)$, nitrate $\left(\mathrm{NO}_{3}{ }^{-}\right)$and ammonium $\left(\mathrm{NH}_{4}{ }^{+}\right)$, and living foraminifera. Following oxygen microsensor profiling each core was further subsampled with three 50 -ml cutoff syringes and one $20-\mathrm{ml}$ cutoff syringe. Of the subsample cores, one $(50 \mathrm{ml})$ was subsequently processed for foraminifera and the other three combined for pore-water analyses. This approach ensured that foraminifera and all geochemical parameters were measured from a single core with an internal diameter of $10 \mathrm{~cm}$.

\subsection{1. $\mathrm{O}_{2}$ profiling}

All oxygen profiles were measured with Unisense OX-100 microelectrodes that were two-point calibrated in 100\% air-saturated filtered site water (obtained by vigorous bubbling with air for $>5 \mathrm{~min}$ ) and an anoxic solution prepared with sodium ascorbate and $\mathrm{NaOH}$, both adjusted to final concentrations of $0.1 \mathrm{M}$ (as outlined in the Unisense $\mathrm{O}_{2}$ microsensor manual). For each core, multiple oxygen profiles were executed at 100- to $200-\mu \mathrm{m}$ depth increments. The profiles ( 9 in August and 6 in February) were done along a single line across the core with approximately $0.5 \mathrm{~cm}$ spacing.

\subsubsection{Pore-water sampling and analyses}

Following the subsampling, the cutoff syringes were placed in a nitrogen-flushed glove bag and the sediment was sliced at $1 \mathrm{~cm}$ intervals down to $10 \mathrm{~cm}$ depth. Samples were transferred into $50 \mathrm{ml}$ centrifuge tubes fitted with $0.45 \mu \mathrm{m}$ maxi-spin centrifuge filters and subsequently centrifuged at $3000 \mathrm{rpm}$ for $20 \mathrm{~min}$ outside the glovebag. Afterwards the tubes were transferred back into the glove bag where obtained pore water was filtered $(0.25 \mu \mathrm{m})$ and divided into subsamples for various analyses. The nutrient analyses of $\mathrm{NO}_{3}{ }^{-}$and $\mathrm{NH}_{4}{ }^{+}$were carried out at the Royal NIOZ according to standard protocols of Grashoff et al. (1983) and Helder (1989), respectively.

\subsubsection{Foraminiferal sampling and cellular ultrastructure}

A subsample of the sediment core (a 50 -ml cutoff syringe) was sliced immediately following the oxygen profiling at $1 \mathrm{~cm}$ intervals down to $10 \mathrm{~cm}$ depth. Ammonia spp. are typically found to inhabit the oxic part of the surficial sediment layer, and as numbers reduce significantly below the level of oxygen penetration (Thibault De Chanvalon et al., 2015), we assume that foraminifera collected from the top $1 \mathrm{~cm}$ were primarily from oxic sediments.

The slices were sieved over a $125-\mu \mathrm{m}$ mesh sieve, and live foraminifera, containing healthy looking and intact cytosol, were picked and processed within $30 \mathrm{~h}$ of sampling. The vitality of all isolated foraminifera was ascertained based on movement of the foraminifera under oxygenated conditions as outlined in Koho et al. (2011). We assumed that the relatively short re-exposure to oxygen would not have substantially influenced the ultrastructure of foraminifera collected below the oxygen penetration depth in sediment. Living specimens were transferred into individual Eppendorf Tubes ( $1.5 \mathrm{ml})$, containing a fixative solution of $2 \%$ glutaraldehyde and $4 \%$ paraformaldehyde in filtered $\left(0.2 \mu \mathrm{m}\right.$ ) seawater (kept in $4{ }^{\circ} \mathrm{C}$; $\mathrm{pH}$ of the solution was not adjusted), in which they were gently mixed, immediately after their vitality was confirmed, in preparation for ultrastructural examination (Table 1). After $24 \mathrm{~h}$, the specimens were transferred into a solution containing $4 \%$ paraformaldehyde in filtered seawater (kept in $4{ }^{\circ} \mathrm{C}$ ), in which they remained until further processing at the University of Helsinki, Finland. In the home laboratory, the specimens were rinsed in filtered seawater and post-fixed in a solution of $2 \%$ osmium tetroxide in filtered seawater for about $1 \mathrm{~h}$. Foraminifera were then decalcified in $0.1 \mathrm{M}$ ethylenediamine tetra acetic acid (EDTA) prepared in distilled water ( $\mathrm{pH} 7.4)$, dehydrated in successive baths of ethanol $(2 \times 15 \mathrm{~min}$ : $50 \% 70 \% 96 \% ; 4 \times 15$ mins:100\%) and in $100 \%$ acetone 
Table 1

Protocols used to prepare specimens for ultrastructural analyses using transmission electron microscopy.

\begin{tabular}{|c|c|c|c|c|}
\hline Treatment & $\begin{array}{l}\text { Field study } \\
\text { Mokbaai }\end{array}$ & $\begin{array}{l}\text { Experiment } 1 \\
\text { Tokyo Bay }^{\mathrm{a}}\end{array}$ & $\begin{array}{l}\text { Experiment } 2 \\
\text { Tokyo Bay }^{\mathrm{b}}\end{array}$ & $\begin{array}{l}\text { Experiment } 3 \\
\text { Aiguillon Bay }^{\mathrm{c}}\end{array}$ \\
\hline Fixation & $\begin{array}{l}\text { Protocol 1: Foraminifera directly fixed in } 2 \% \\
\text { glutaraldehyde, } 4 \% \text { paraformaldehyde in filtered } \\
\text { seawater. After } 24 \mathrm{~h} \text { specimens were transferred } \\
\text { to } 4 \% \text { paraformaldehyde in filtered seawater. }\end{array}$ & $\begin{array}{l}\text { Protocol 2: Foraminifera } \\
\text { directly fixed in } 2.5 \% \\
\text { glutaraldehyde in filtered } \\
\text { seawater. }\end{array}$ & $\begin{array}{l}\text { Protocol 3: Sediments were fixed in } 10 \% \\
\text { glutaraldehyde in cacodylate buffer to a } \\
\text { final concentration of } 4.0 \% \\
\text { glutaraldehyde. Foraminifera isolated } \\
\text { later. }\end{array}$ & $\begin{array}{l}\text { Protocol 4: Foraminifera } \\
\text { directly fixed in } \\
\text { glutaraldehyde } 4 \% \text { in } 0.1 \mathrm{M} \\
\text { cacodylate buffer. }\end{array}$ \\
\hline Post-fixative & $\mathrm{OsO}_{4}(2 \%)$ & $\mathrm{OsO}_{4}(2 \%)$ & $\mathrm{OsO}_{4}(2 \%)$ & $\mathrm{OsO}_{4}(2 \%)$ \\
\hline Staining & UA $(0.5 \%)$ and $\mathrm{Pb}(3 \%)$ & UA $(1 \%)$ and $\mathrm{Pb}(0.3 \%)$ & $\mathrm{UA}(1 \%)$ and $\mathrm{Pb}(0.3 \%)$ & UA only $(2 \%)$ \\
\hline Resin & Taab low viscosity medium resin & $\begin{array}{l}\text { Epon } 812 \text { resin (Taab } \\
\text { Laboratory Equipment) }\end{array}$ & $\begin{array}{l}\text { Quetol } 651 \text { resin (Nisshin EM, Tokyo, } \\
\text { Japan) }\end{array}$ & LR white resin \\
\hline $\begin{array}{l}\text { Section } \\
\text { thickness }\end{array}$ & $60 \mathrm{~nm}$ & $60 \mathrm{~nm}$ & $60 \mathrm{~nm}$ or $200 \mathrm{~nm}$ & $70 \mathrm{~nm}$ \\
\hline $\begin{array}{l}\text { Acceleration } \\
\text { voltage }\end{array}$ & $80 \mathrm{kV}$ & $120 \mathrm{kV}$ & $120 \mathrm{kV}$ & $80 \mathrm{kV}$ \\
\hline
\end{tabular}

a Nomaki et al. (2014).

c LeKieffre et al. (2017)

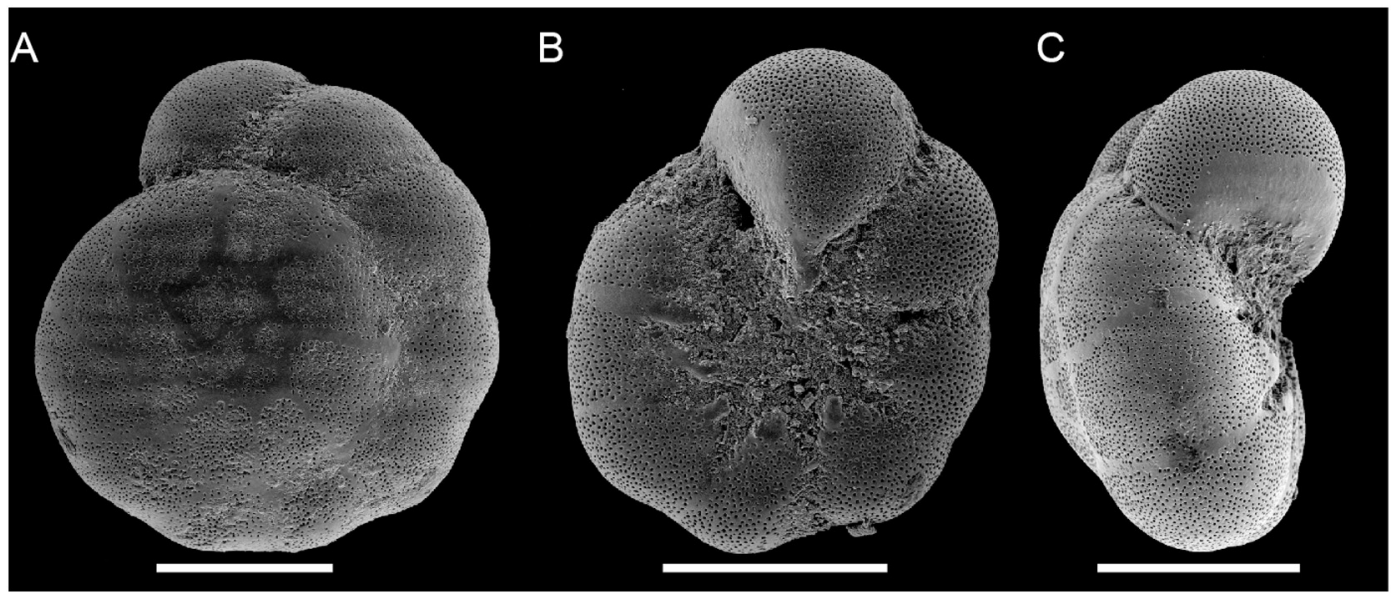

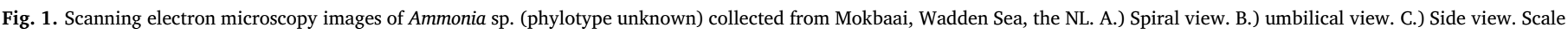
bars $=200 \mu \mathrm{m}$.

$(2 \times 10 \mathrm{~min})$, and embedded in Taab low viscosity medium resin. The resin was cut into ultrathin sections using a diamond blade, and mounted on single slot grids. Samples were stained with uranyl acetate $(0.5 \%)$ and the ultrathin sections (typically cut on horizontal plane of foraminifera, spiral view visible), were examined with Jeol JEM-1400 transmission electron microscope (TEM). In total, 3 specimens of Ammonia sp. (phylotype unknown, Fig. 1) from surficial $(0-1 \mathrm{~cm}$ depth) and 5 specimens from anoxic sediments $(7-8 \mathrm{~cm}, 8-9 \mathrm{~cm}$ and $9-10 \mathrm{~cm}$ depth intervals) were observed under TEM.

\subsection{Experimental studies: Foraminifera from oxic and anoxic incubations}

Foraminifera from three separate incubation studies were used for ultrastructural analyses. For Experiment 1, specimens of Ammonia sp., (phylotype T6, M. Tsuchiya pers. com.) were collected from surface sediments $(0-1 \mathrm{~cm}$ depth) of the Nojima tidal mud flat (Tokyo Bay, Japan) in June 2011 and subsequently incubated with in situ sediment in oxic and anoxic conditions for one month. Oxic bottles were kept open and thoroughly mixed daily, allowing diffusion of oxygen from atmosphere into the seawater and sediment. Evaporation, and subsequent changes in salinity, was minimized by storing the incubation bottles in a sealed plastic box. Anoxic conditions were induced by closing the bottles without any headspace gas. Anoxia developed within 2-3 days, and oxygen concentrations were monitored with a Unisense oxygen microelectrode. For imaging, 5 oxic and 5 anoxic specimens were used. In Experiment 2, Ammonia sp. (phylotype T6) were collected in March 2014 from the same site and incubated with in situ sediment in anoxic and dysoxic conditions for 14 days. Anoxic conditions were induced as in Experiment 1. Dysoxic conditions were created by allowing diffusion of air into the experimental syringes, and oxygen concentrations, corresponding to dysoxic conditions, were monitored with a Unisense oxygen microelectrode. For imaging, 3 oxic and 3 dysoxic specimens were used. Further details of the sample location and experimental design of Experiments are outlined in Nomaki et al. (2014) and Nomaki et al. (2016), respectively. For Experiment 3, Ammonia sp. (phylotype T6; M. Schweizer, unpublished data) were collected from surface sediments (top $2 \mathrm{~cm}$ ) of the intertidal mudflat of Aiguillon Bay (France) and incubated in a thin bed of freeze dried Chlorella algae in oxic and anoxic conditions for 13 days. Oxic conditions were maintained by continuous bubbling with air. Anoxia was induced and maintained by bubbling with a mixture of $\mathrm{N}_{2}$ and $0.04 \%$ $\mathrm{CO}_{2}$ (Air liquide, France; purity: 99.999\% $\mathrm{N}_{2}$ and $99.99 \% \mathrm{CO}_{2}$ ). Oxygen concentrations were continuously measured with Unisense microelectrodes. For imaging, 3 oxic and 2 anoxic specimens were used. Further details of the experimental design are outlined in LeKieffre et al. (2017). Intact mitochondria were observed in the cells of all studied specimens, indicating they were alive at the time of fixation.

The specimens were prepared for ultrastructural analyses in a similar fashion to the ones outlined in Section 2.2.; however, some differences exist between the protocols, which are summarized in Table 1. The different protocols may have led to slight variations in image quality and appearance of the organelles (Table 2). 
Table 2

Fixation protocols applied to specimens imaged in Figs. 3-8. For details on the various protocols, see Table 1 "fixation".

\begin{tabular}{|c|c|c|c|c|}
\hline & Protocol 1 & Protocol 2 & Protocol 3 & Protocol 4 \\
\hline Fig. 3 & All images & & & \\
\hline Fig. 4 & & Images $\mathrm{A}-\mathrm{C}$ & & Images D-F \\
\hline Fig. 5 & All images & & & \\
\hline Fig. 6 & Images A-C & Image D & & Image $\mathrm{E}$ \\
\hline Fig. 7 & Images A-B & Images D-F & & Image C \\
\hline Fig. 8 & & & $\begin{array}{l}\text { Image E (200 nm); Images F-G } \\
(60 \mathrm{~nm})\end{array}$ & Images A-D \\
\hline
\end{tabular}

\subsection{Image treatment}

Image treatment and analysis of the TEM images of Experiment 3 was performed in Fiji and Adobe Photoshop (Schindelin et al., 2012). Harmonic noise from vibrations during ultra microtomy was removed in images a-d in Fig. 8 by blocking distinct low spatial frequencies in their corresponding Fourier image and performing an inverse Fourier transform for a reconstructed image. In cases of different phases of noise in the same image due to cutting properties of, e.g., resin vs. sample, the images were divided in Photoshop, Fourier filtering was performed on each image and the reconstructed images were stitched back together. Original images are available upon request. No image treatment was carried out on images from field-collected specimens or Experiments 1 and 2 specimens.

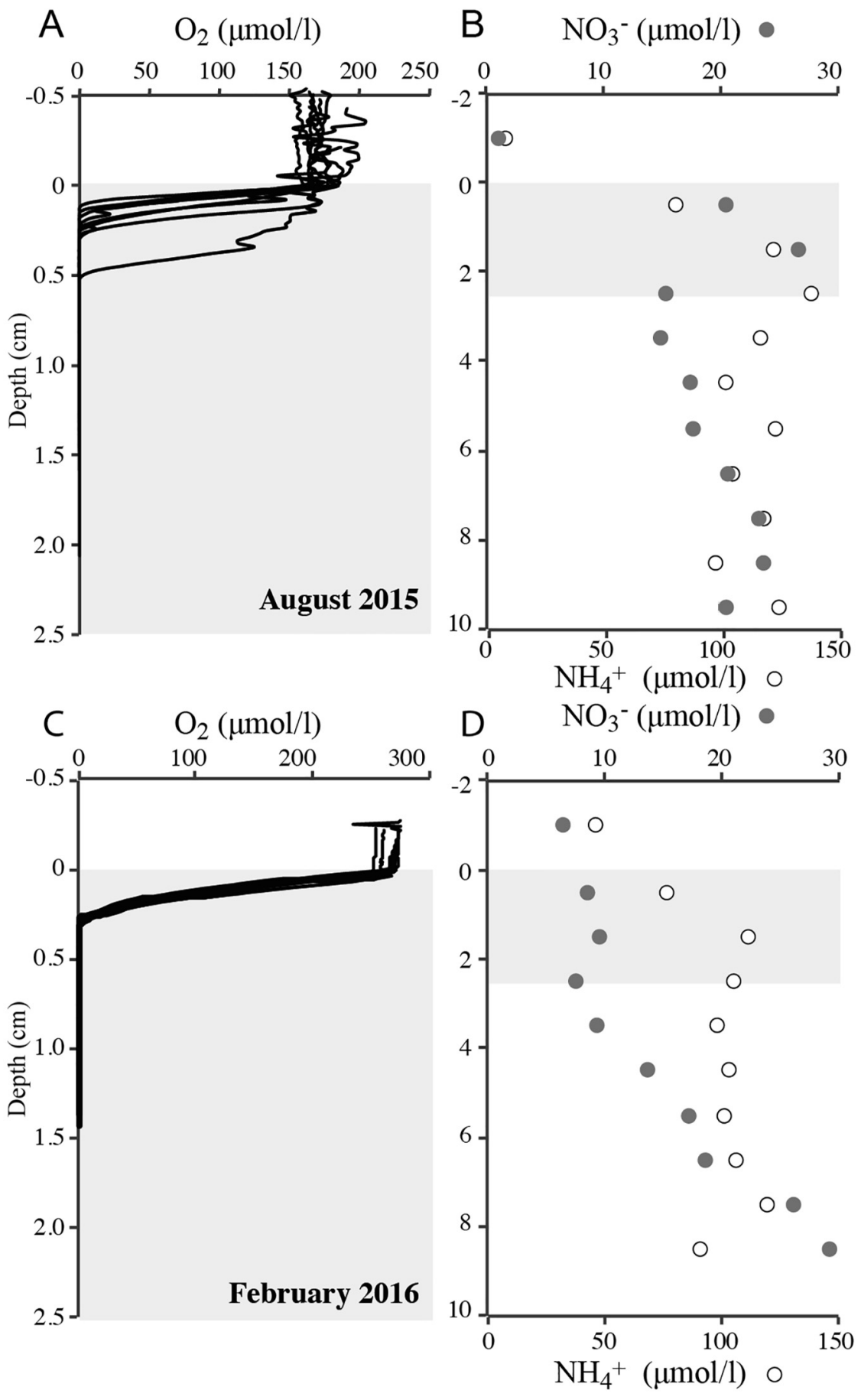

2. Pore-water profiles of oxygen $\left(\mathrm{O}_{2}\right)$, nitrate $\left(\mathrm{NO}_{3}{ }^{-}\right)$and ammonium $\left(\mathrm{NH}_{4}{ }^{+}\right)$from Wadden Sea tidal mudflat (Mokbaai). A-B.) Core collected in August 2015. C-D.) Core collected in February 2016. 

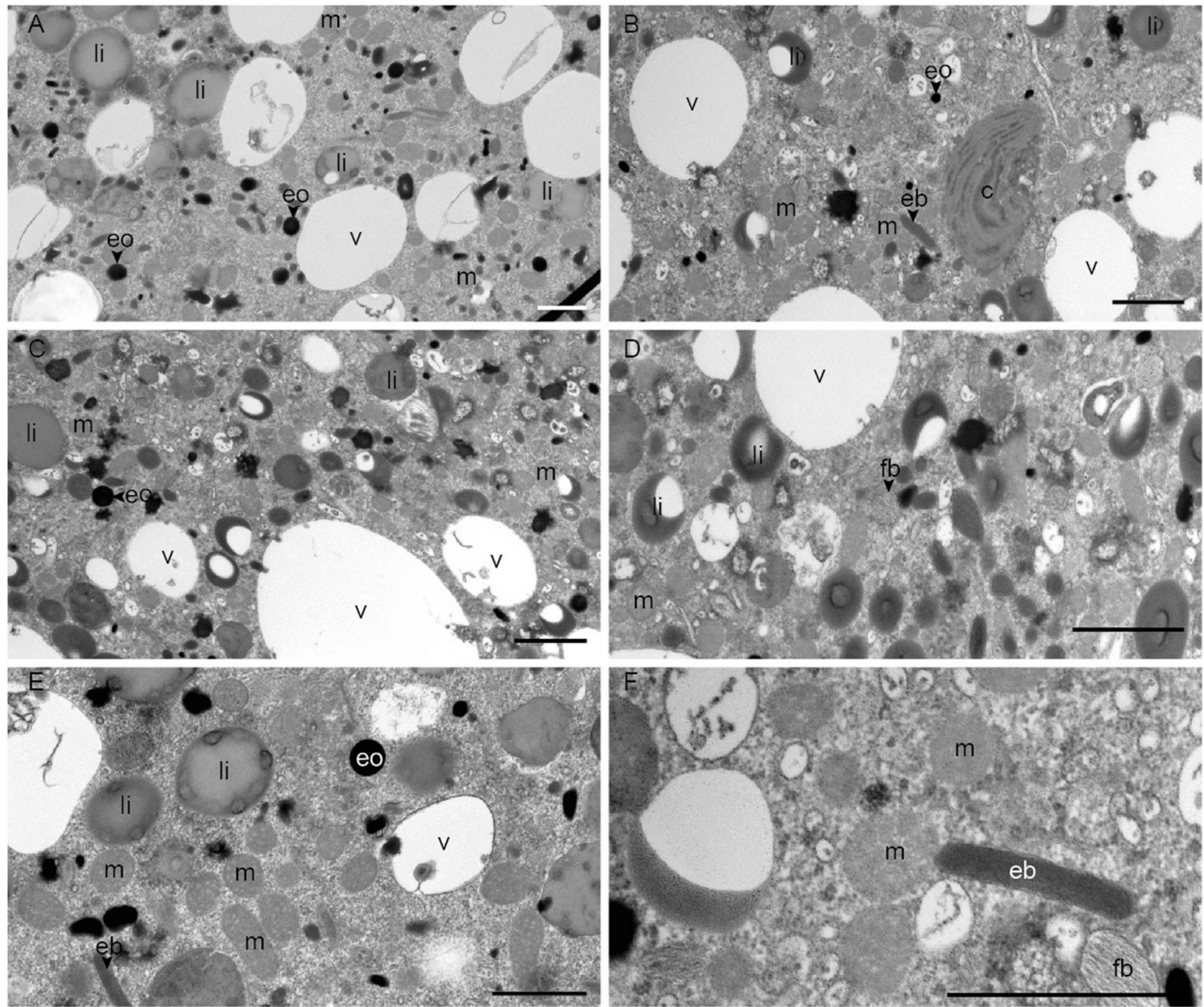

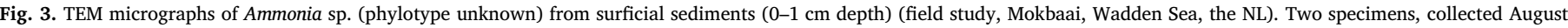
2015. $\mathrm{li}=$ lipid droplet, $\mathrm{v}=$ vacuole, $\mathrm{m}=$ mitochondrion, eo $=$ electron dense opaque body, $\mathrm{c}=$ choloroplast, $\mathrm{eb}=\mathrm{elongated}$ body, $\mathrm{fb}=$ fibrillar vesicle. Scale bars $=1 \mu \mathrm{m}$.

\section{Results}

\subsection{Porewater geochemistry of foraminiferal microhabitat at Mokbaai sediments}

The oxygen penetration depth in the Mokbaai sediments was very shallow, ranging in general from $0.1 \mathrm{~cm}$ to $0.25 \mathrm{~cm}$ for individual microsensor profiles (Fig. 2). Only a single profile measured in August 2015 indicated somewhat deeper oxygen penetration, reaching a depth of $0.5 \mathrm{~cm}$. As the oxygen penetration depth was $<1 \mathrm{~cm}$, the foraminifera collected from the surficial sediments $(0-1 \mathrm{~cm})$ came from a mixed oxic-to-anoxic sediment layer.

In both in August and February, the pore water nitrate $\left(\mathrm{NO}_{3}{ }^{-}\right)$ concentrations were relatively high, reaching close to $30 \mu \mathrm{mol} / \mathrm{l}$, in deeper sediment intervals (Fig. 2). In August, no systematic trends were seen in the $\mathrm{NO}_{3}{ }^{-}$data whereas in February the $\mathrm{NO}_{3}{ }^{-}$concentrations seemed to increase with sediment depth. In both cases, $\mathrm{NO}_{3}{ }^{-}$production was clearly taking place in these deeper sediment units. In general, detectable porewater nitrate was present in sediment units sampled for foraminifera.

Ammonium $\left(\mathrm{NH}_{4}{ }^{+}\right)$production was occurring below the depth of oxygen penetration in the anoxic sediment (Fig. 2). The concentrations below $1 \mathrm{~cm}$ depth were generally high (over $100 \mu \mathrm{mol} / \mathrm{l}$ ).

\subsection{Ultrastructural observations of Ammonia spp. from surficial sediments and oxic incubations}

The ultrastructure of Ammonia sp. (phylotype unknown) collected from Mokbaai surface sediment or from oxic incubations looked healthy, typically containing a dense cytosol (Figs. 3, 4). Organelles, such as mitochondria and fibrillar vesicles, were relatively common and easy to identify (Figs. 3A, E, F, 4C, F). In addition, elongated bodies (Figs. 3F, 4B), lipid droplets (generally small and measuring around $1-2 \mu \mathrm{m}$ in diameter (Figs. 3A, C, E, 4D, E)) and randomly scattered electron dense bodies were found (Figs. 3E, 4F). Nucleus, Golgi, endoplasmic reticulum and peroxisomes were also present (not shown in figures). Less common, but still occasionally present, were chloroplasts (Fig. 3B) and empty diatom frustules (Fig. 4A).

\subsection{Ultrastructural observations of Ammonia spp. from anoxic sediments} and incubations

The ultrastructure of living specimens that were collected from Mokbaai, Wadden Sea, at sediment depths with no detectable porewater oxygen, and from anoxic experiments (Figs. 5-8) looked visually different to the ones collected from the surficial sediments or from oxic incubations (Figs. 3, 4). For example, the cytosol of foraminifera from anoxic Mokbaai sediments was generally less electron dense (Fig. 5) than the cytosol of specimens collected from surficial field sediments (Fig. 3) or from oxic incubations (Fig. 4). In addition, the size of the lipid droplets seemed to have increased, generally exceeding $2 \mu \mathrm{m}$ in diameter and reaching over $5 \mu \mathrm{m}$ in diameter in some specimens (Figs. 5, 6). In the anoxic incubation (Experiment 1), multiple lipid droplets were also observed in single vacuoles (Fig. 6D).

Numerous intact bacteria were also found in specimens recovered oxygen-depleted field sediments and in specimens incubated in anoxic conditions (Fig. 7). The shape of the bacteria ranged from coccoid (e.g., Fig. 7A, B) to more rod-shaped (e.g., Fig. 7C). Bacteria were also observed dividing inside the foraminiferal cell (Fig. 7C, F). In addition, bacteria were found inside possible degradation vacuoles (Figs. 5D, 7B). 

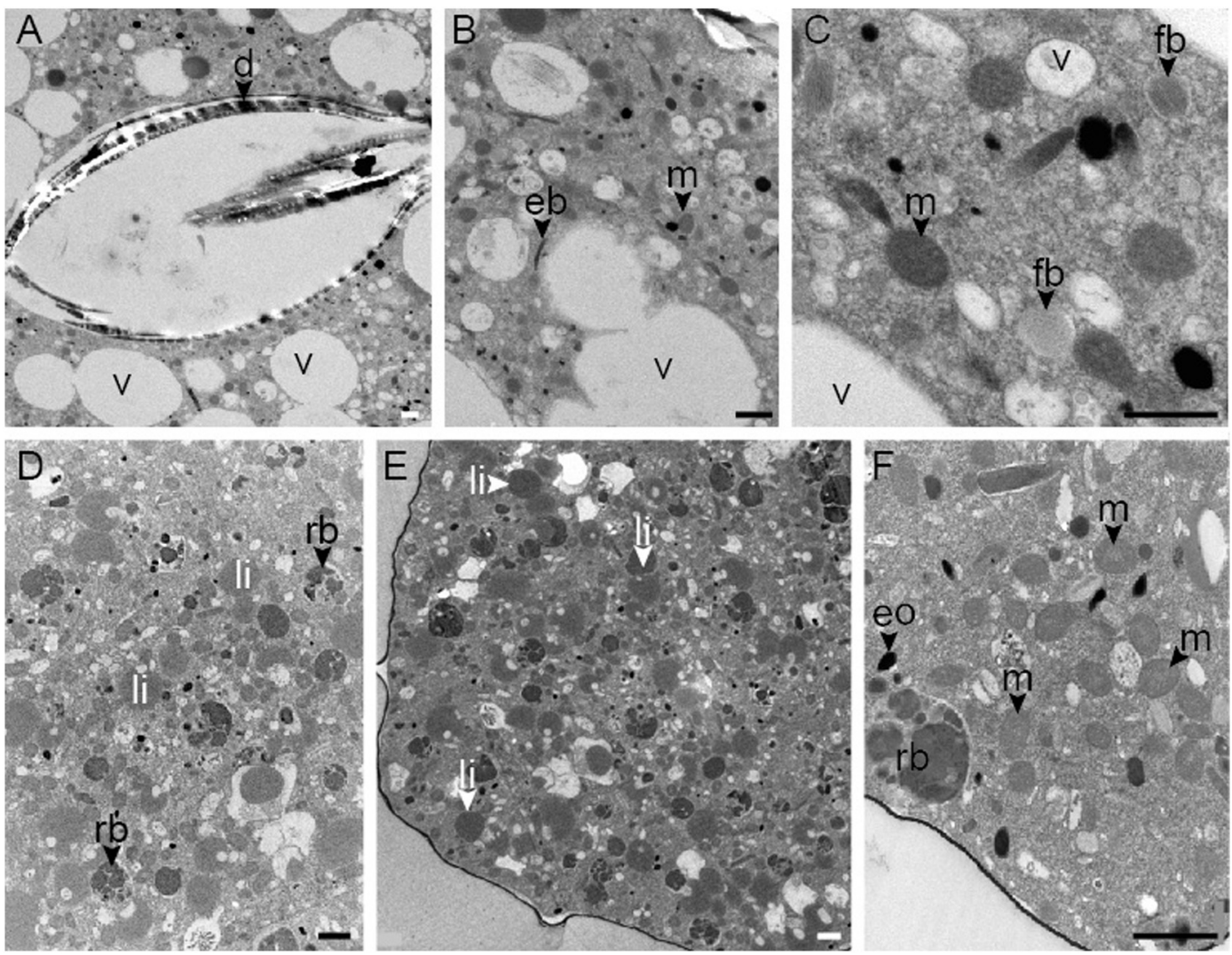

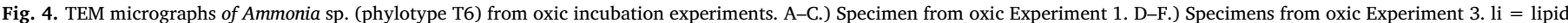

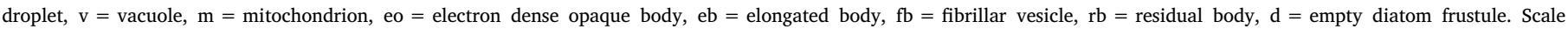
bars $=1 \mu \mathrm{m}$

Other ultrastructural features noted only in the specimens incubated in anoxic conditions included the presence of lipid droplets between the plasma membrane and the organic lining, an apparent increase in the thickness of the organic lining, and aggregation of electron dense bodies (Fig. 8).

Mitochondria were observed in specimens from anoxic sediments and incubations (Figs. 5A, B and 7E). The mitochondria were distributed randomly throughout the foraminiferal cytosol.

\section{Discussion}

\subsection{Signs of stress in Ammonia spp. under anoxia}

Lipid droplets were observed to be enlarged in specimens collected from anoxic conditions, generally measuring over $2 \mu \mathrm{m}$ in diameter, with droplets measuring over $5 \mu \mathrm{m}$ in diameter found in the field samples (Figs. 5, 6). In addition, the area of the cell covered by the lipid droplets appeared visually more extensive in specimens from anoxic conditions (both from field and experimental studies) compared to specimens recovered from oxygenated incubations or surficial field sediments (Fig. 6). However, further quantitative studies with more specimens are needed to confirm the apparent increase in lipid content under anoxia. Multiple lipid droplets were also observed within single vacuoles (Fig. 6D) in specimens from the anoxic incubations. Occurrence of increased intracellular lipid has been described as a classic symptom of hypoxic cell injury in cellular pathology (e.g., Gordon et al., 1977 and references therein). Other environmental stressors, such as heavy metal toxicity, have been linked to increases in the lipid contents of both marine dinoflagellates (Prévot and Soyer, 1978) and benthic foraminifera (Le Cadre and Debenay, 2006; Frontalini et al., 2016; Frontalini et al., 2017). In mammals, lipid droplet formation has been shown to be a cellular response to detrimental environmental conditions, with cells switching from oxidative phosphorylation to glycolysis and fatty acid synthesis in response to mitochondrial dysfunction, and sequestering resources in lipid droplets (Lee et al., 2013). In Ammonia spp. (phylotype 6 and phylotype unknown), the observed changes in lipid accumulation and increased droplet size indicate that the cells experienced severe stress in the absence of oxygen.

The stress response to anoxia was further confirmed by additional ultrastructural changes observed in Ammonia spp. (phylotype 6 and phylotype unknown). In the anoxic incubations, lipid droplets were noted in the space between the plasma membrane and the organic lining (Fig. 8A, B), implying a disruption of the plasma membrane. In addition, the thickness of the organic lining seemed to have increased (Fig. 8C, D, E), although further studies are needed to affirm this observation. Similar ultrastructural changes, attributed to environmental stressors, were found in foraminifera incubated in high heavy metal concentrations (Le Cadre and Debenay, 2006) and in foraminifera exposed to oil (Morvan et al., 2004), suggesting that this ultrastructural modification is a common stress response.

The ultrastructural changes in response to stress were not identical in all specimens studied, and the differences noted between the anoxic field and experimental observations are difficult to interpret due to the limited number of specimens. Furthermore, it is not possible to know how long the field specimens had been exposed to anoxic conditions. Different stages of cytosol thinning, associated with the largest lipid droplets, suggest that some specimens had been under anoxic conditions longer than others (e.g., compare Fig. 5C, D with Fig. 5E, F). Handling of foraminifera during setting up the experiment (e.g., sieving and sorting) and the experimental conditions themselves (e.g., lack of sediment substrate) may have also caused additional impacts to the foraminifera, hence the field and experimental specimens may not be directly comparable. 

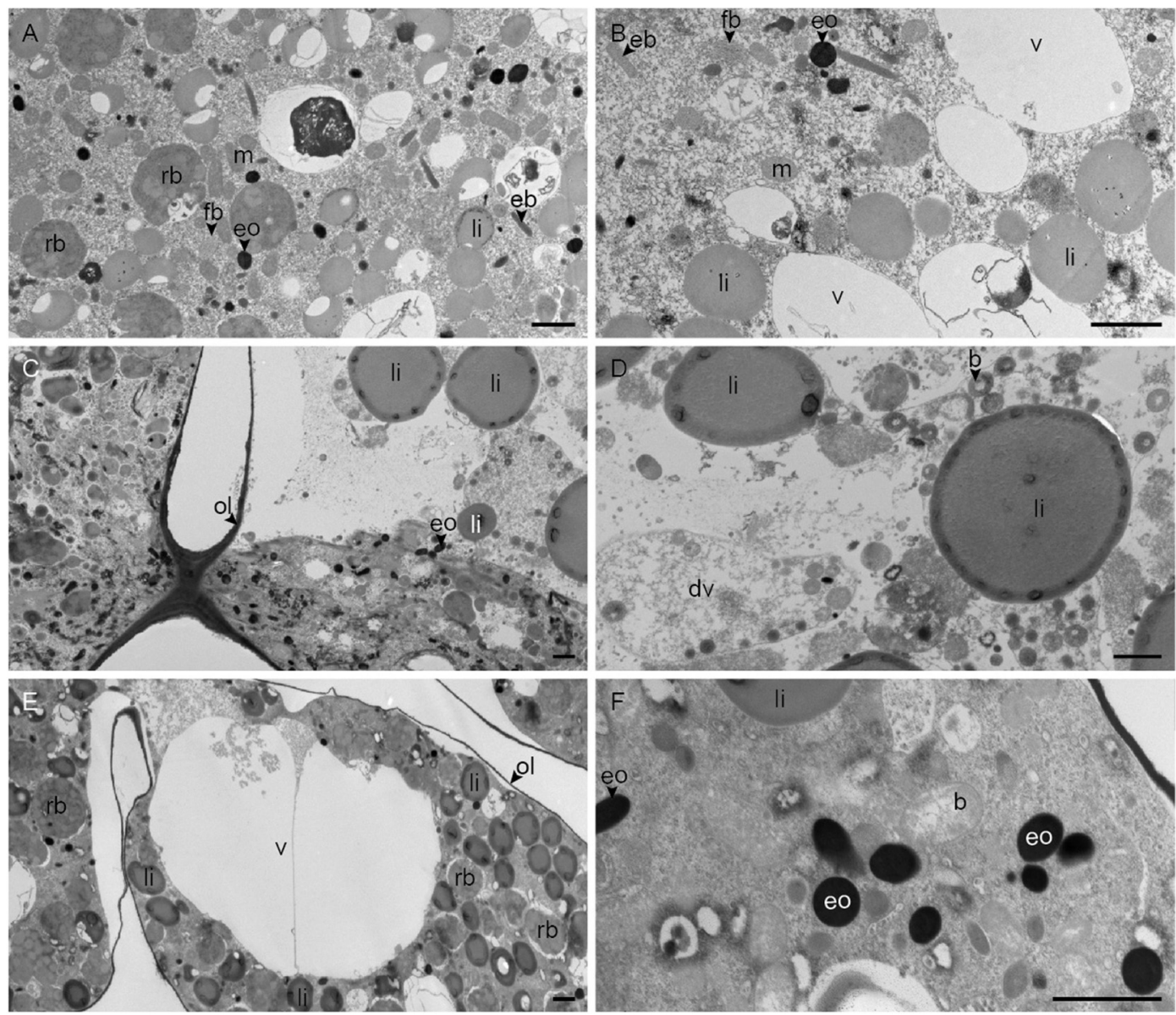

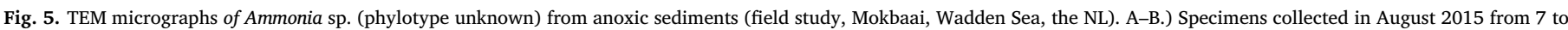

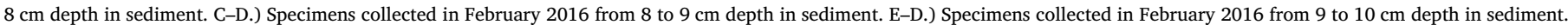

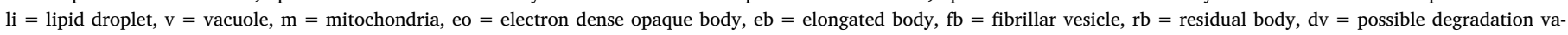
cuole. Scale bars $=1 \mu \mathrm{m}$.

\subsection{Potential bacterial endosymbionts in the foraminiferal cytosol after anoxic exposure}

Bacteria were only observed in specimens from anoxic conditions (both field samples and experimental incubations), and not seen in foraminifera collected from surficial sediments collected from Mokbaai or from the oxic incubations. Bacteria present in Ammonia spp. (phylotype 6 and phylotype unknown) appeared intact, and some cells were also observed to be dividing (Fig. 7C, F), thus implying bacterial reproduction inside the host cytosol. The morphology of the bacteria differed, ranging from coccoid in foraminifera collected from the Mookbai sediments to more rod-shaped in the specimens from the experimental incubations. The morphology of the bacterial cells also differed between specimens of Ammonia sp. (phylotype T6) collected during different seasons from the same field site in Tokyo Bay (Nomaki et al., 2014, 2016). The ultrastructural observations, therefore, suggest that during anoxic exposure, Ammonia spp. (phylotype 6 and phylotype unknown) may be a host to various species of intracellular bacteria, and that the bacterial assemblages comprising the foraminiferal microbiome may change in time and space. Various endobionts have been described for other foraminiferal species that inhabit anoxic sediments (e.g., Bernhard, 2003; Bernhard et al., 2012; Tsuchiya et al., 2015; Bernhard et al., 2017). Therefore, the presence of bacterial endobionts in foraminifera coming from anoxic sediments seems relatively widespread. The function of the potential bacterial endobionts requires further examination.

Foraminiferal denitrification is a widespread phenomenon, both geographically and phylogenetically speaking (Piña-Ochoa et al., 2010) and, at least in allogromiid foraminifers, it is likely catalyzed by the endobionts, providing its host an advantage in anoxic environments (Bernhard et al., 2012). The ability to carry out denitrification could also explain the survival of Ammonia spp. (phylotype 6 and phylotype unknown) in anoxic conditions; however, denitrification capacity was not detected in Ammonia spp. (Piña-Ochoa et al., 2010). Nitrate accumulation capacity seems also very limited in Ammonia spp. (Piña-Ochoa et al., 2010; Geslin et al., 2014), although the relatively high concentrations of pore-water nitrate (Fig. 2) in the intertidal sediments could potentially allow Ammonia sp. (phylotype unknown) to respire nitrate without the need to concentrate nitrate intracellularly.

In addition to denitrification, the endosymbionts in Ammonia spp. (phylotype 6 and phylotype unknown) may be able to carry out other biogeochemical pathways in the nitrogen cycle. The results of Nomaki et al. (2014) suggest that bacteria found in the Ammonia sp. (phylotype T6) are actively involved in amino acid synthesis and other nitrogenassimilation processes, and might not be related to anaerobic respiration. In a study by Nomaki et al. (2016), multiple electron dense bodies (Fig. 8) were reported to co-occur with the possible bacterial endobionts, both in dysoxic and anoxic incubations, and observed to align along the cell periphery. The function of the electron dense bodies and their co-occurrence with the possible endobionts is not currently clear, but they are likely to play an important role in foraminiferal nitrogen metabolism as ${ }^{15} \mathrm{~N}$-labeled nitrogen, originating from ${ }^{15} \mathrm{~N}$-labeled nitrate, was found to be assimilated in electron dense bodies (Nomaki et al., 2016). Furthermore, the role of the electron dense bodies may 


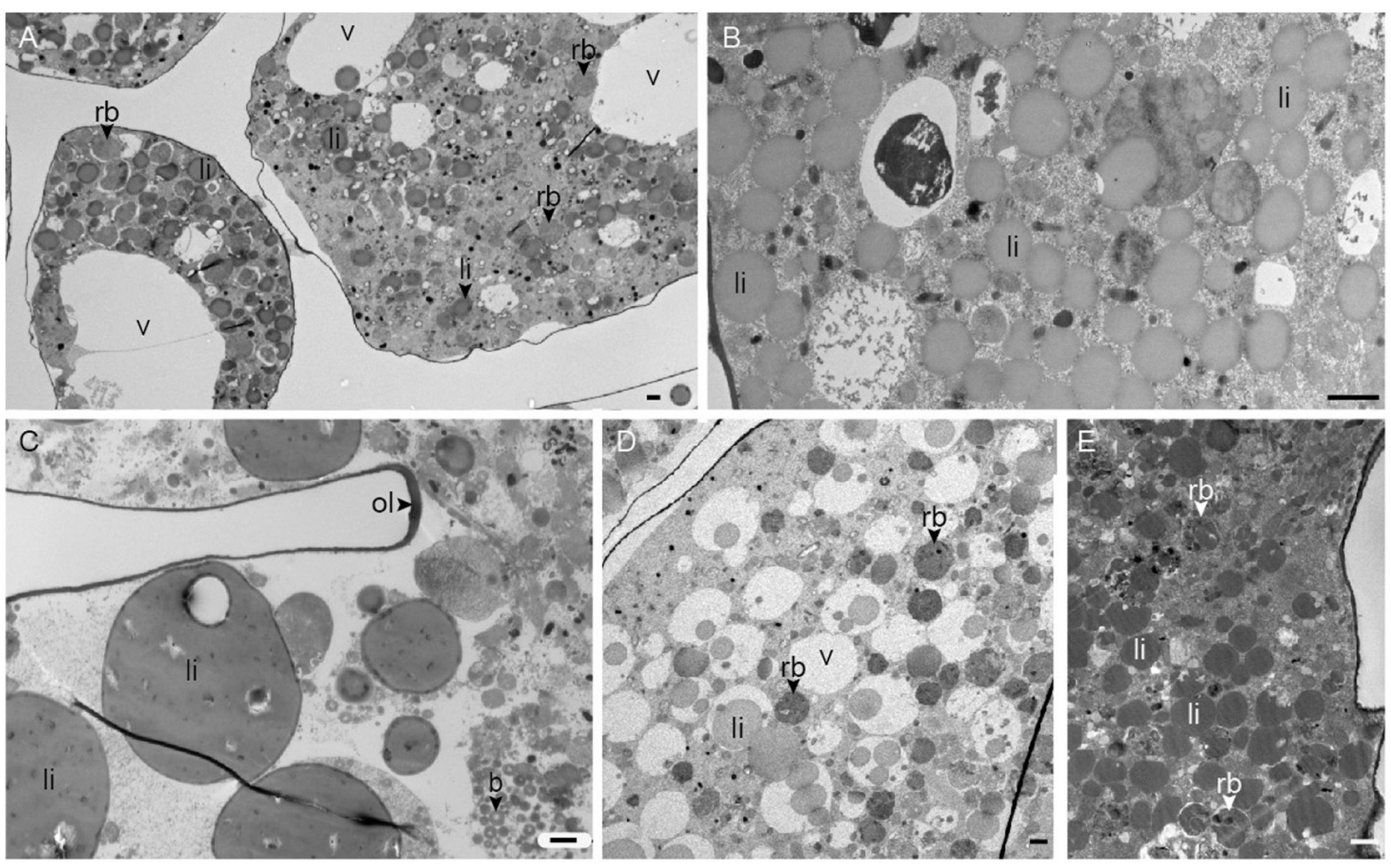

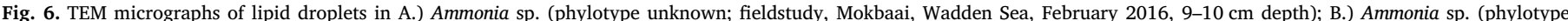

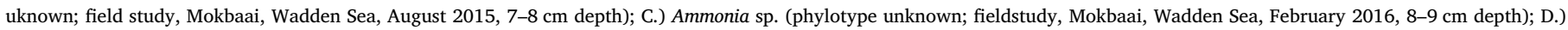

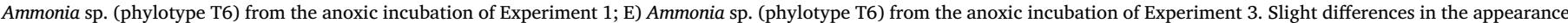

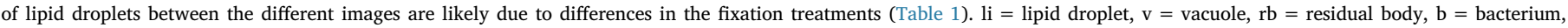
ol $=$ organic lining. Scale bars $=1 \mu \mathrm{m}$.
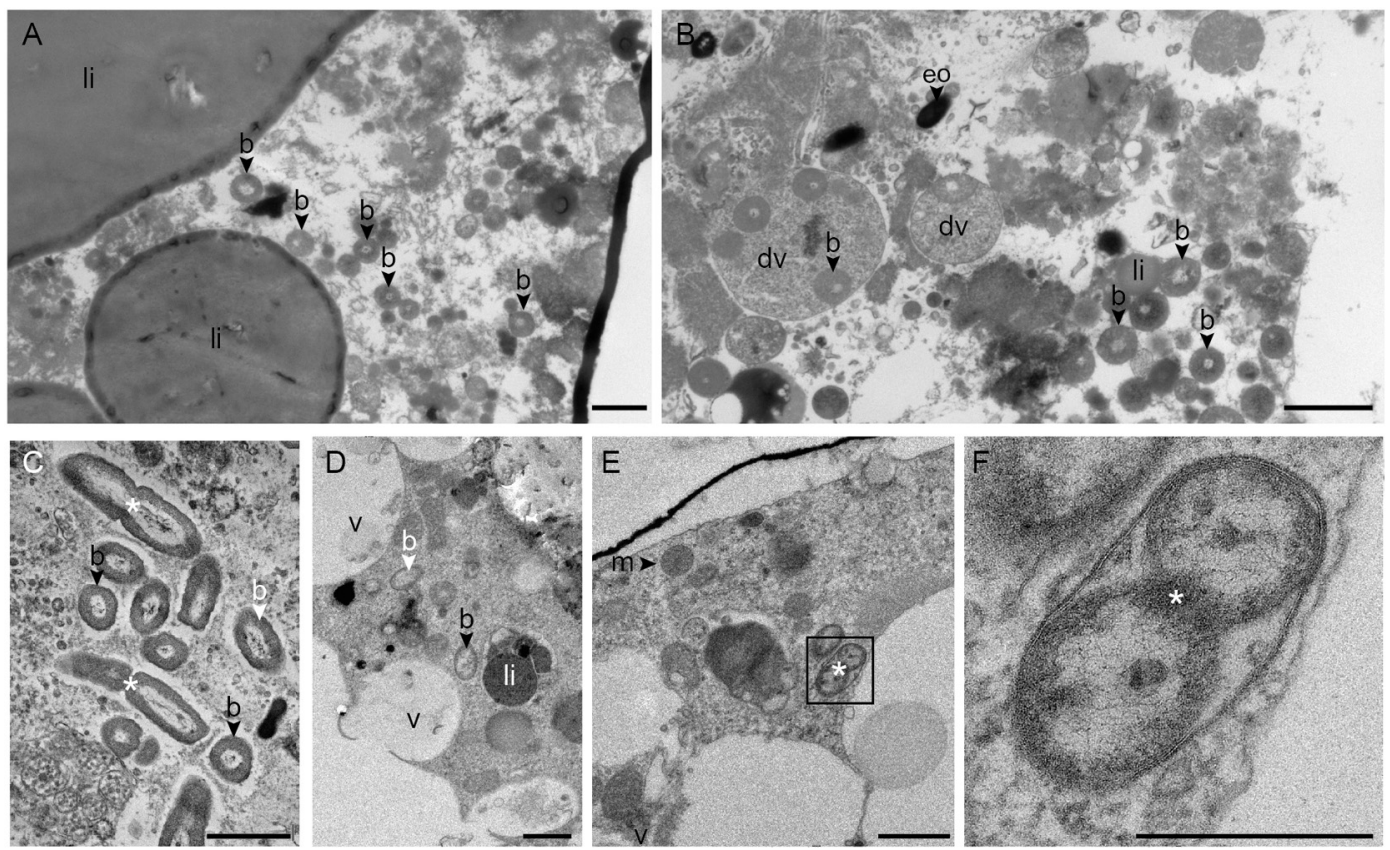

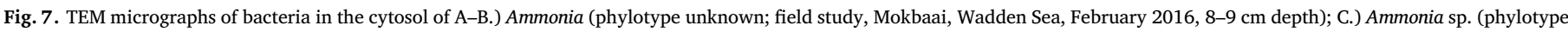

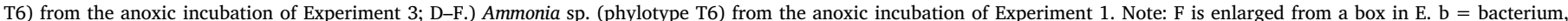

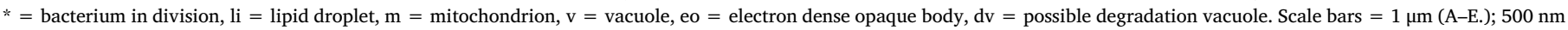
(F.).

also be linked to sulfate assimilation in Ammonia sp. (phylotype T6) (Nomaki et al., 2016), as ${ }^{34}$ S-labeled sulfate was incorporated into the electron dense bodies in specimens incubated in dysoxic conditions. Those authors conclude that the sulfate activation pathway may be related to foraminiferal dormancy or encystment under anoxia in a manner similar to Entamoeba histolytica (Mi-ichi et al., 2011, 2015).

\subsection{Evidence for the potential dormancy of Ammonia spp. under anoxia}

The structure of the cytosol of Ammonia sp. (phylotype unknown) from deeper anoxic sediments (Mokbaai, the NL) appeared different from that of specimens collected from surficial sediments and from oxic incubations, in that the cytosol was generally less electron dense in the anoxic specimens (compare Figs. 3 and 4 with Fig. 5). The thinning of 

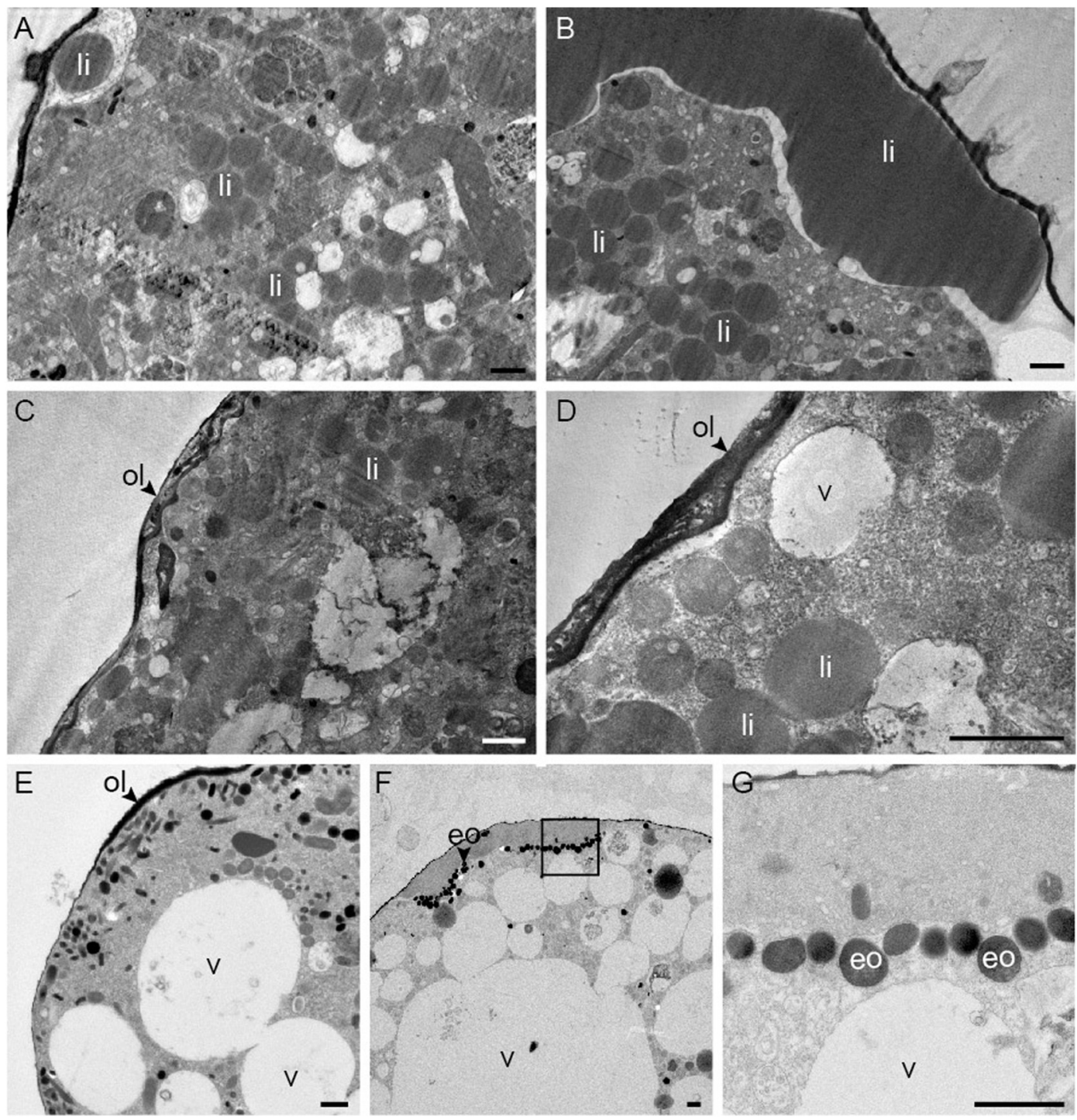

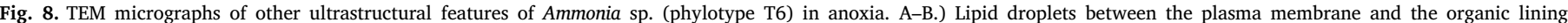

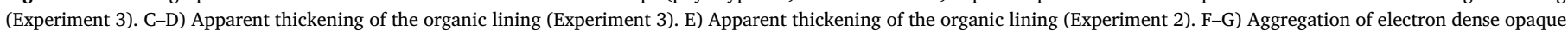

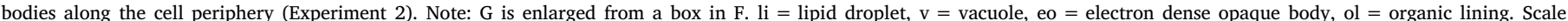
bars $=1 \mu \mathrm{m}$.

the cytosol suggests that foraminifera are most likely not actively feeding when exposed to anoxic, hostile conditions. Instead, foraminifera could be in a state of dormancy and sustaining metabolism by consuming its own cytosol, which subsequently becomes less dense. In deep-sea foraminifera, similar behavior has been described in environments where food-supply is seasonally limited and at times the flux of organic detritus arriving on the sea floor is very low (Linke, 1992). During periods of starvation foraminifera are able to maintain metabolic activity by metabolizing their own cytosol (Linke, 1992). Additionally, recent results by LeKieffre et al. (2017) showed that in anoxic conditions Ammonia sp. (phylotype T6) stopped feeding, decreased their metabolism and became dormant.

If individuals of Ammonia spp. (phylotype 6 and phylotype unknown) were to reduce their metabolism under anoxic conditions their oxygen demand would also subsequently be lowered. As the porewater nitrate profiles from Mokbaai indicate production of nitrate, or nitrification, in these deeper sediment intervals (Fig. 2), micro-oxic conditions, or microenvironments with free oxygen, may at least periodically exist in deeper sediment units. Intertidal sediments can be very heterogeneous and tidal activity and bioturbation are known to significantly influence oxygen and nitrogen dynamics in these settings (e.g., Aller and Aller, 1998; Taillefert et al., 2007; Bonaglia et al., 2014). The intertidal mudflat of Mokbaai is also known to be heavily bioturbated (Hongguang et al., 1995), and during core processing large polychaete worms (several $\mathrm{cm}$ in size) were seen especially deep in the sediment, occurring generally from a depth of $5 \mathrm{~cm}$ but burrowing well below 10-cm depths in sediment. As such it is possible that Ammonia sp. (phylotype unknown) collected from deeper sediment intervals are intermittently respiring oxygen in micro-oxic sediment niches, and surviving by dormancy and/or reduction of their metabolic rate when oxygen is unavailable. This hypothesis is also supported by the observations of Nomaki et al. (2016) who noted reduced foraminiferal activity and lower uptake of labeled nitrate and sulfate in anoxic incubations in contrast to dysoxic incubations.

\subsection{Future directions}

Future studies aiming to investigate changes in foraminiferal ultrastructure in response to variations in sedimentary redox conditions are needed to confirm and further clarify observations of this study. Measurements of additional specimens from natural oxic and anoxic sediments, as well as from well-designed experimental studies, could 
verify and strengthen the results presented here. Application of threedimensional approaches (i.e., tomography, serial sectioning and 3D Serial Block Face Scanning Electron Microscopy Imaging) could help to resolve variations in foraminiferal ultrastructure in response to anoxia, for example, allowing quantification of specific organelles (Nomaki et al., 2015, 2017). In particular, quantification of foraminiferal lipid droplets and the total bio-volume occupied by the lipid droplets can be accurately measured with 3D Serial Block Face Scanning Electron Microscopy Imaging. These measurements could elucidate the potential increase in the biovolume of total lipids in foraminifera in response to anoxia. Detailed and systematic quantification of other organelles, including mitochondria, with 3D imaging could also be beneficial, as previous work has shown that foraminifera from low-oxygen settings may contains less mitochondria or mitochondria show specific organization within the cell (e.g., Bernhard, 1996 and references therein).

\section{Conclusions}

Ultrastructural studies can provide important insights into the physiology of foraminifera and their adaptive or coping strategies under different environmental conditions. In this study, a clear stress response was seen in Ammonia spp. (phylotype 6 and phylotype unknown) recovered from anoxic, natural sediments and anoxic incubations compared to conspecifics from aerated conditions. Apparent accumulation of lipid droplets, a classic response in cell pathology, was observed in specimens from anoxic sediments or incubations. In addition, the size of the lipid droplets appeared to increase in some specimens. At the same time, the cytosol was observed to become thinner, suggesting that foraminifera are not actively feeding but metabolizing their own cytosol under anoxia. Furthermore, endobionts were found only in Ammonia spp. (phylotype 6 and phylotype unknown) from anoxic field sediments and anoxic incubations. The role of the endobionts remains enigmatic. Overall, our observations imply that the shallow-water foraminifera Ammonia spp. (phylotype 6 and phylotype unknown) may be able to survive anoxic conditions for extended periods by dormancy and/or reduced metabolism, but that anoxic conditions are not its optimum habitat.

\section{Acknowledgements}

Susan Richardson and an anonymous reviewer are acknowledged for their critical assessment of an earlier version of this manuscript. Their comments significantly improved this paper. Magali Schweizer is thanked for her valuable advice of taxonomy and nomenclature of Ammonia spp. The Academy of Finland (Project numbers: 278827, 283453) and the French national EC2CO program (CNRS INSU) (project $\mathrm{N}$-Forlab) are acknowledged for funding of this research. The Electron Microscopy unit of University of Helsinki, Florence Manero from the SCIAM platform at the University of Angers (France) and Katsuyuki Uematsu and Akihiro Tame (Marine Works, Japan) are thanked for their help and assistance with the TEM imaging and/or sample preparation. The contribution was edited by Joan Bernhard.

\section{References}

Aller, R.C., Aller, J.Y., 1992. Meiofauna and solute transport in marine muds. Limnol. Oceanogr. 37 (5), 1018-1033.

Aller, R.C., Aller, J.Y., 1998. The effect of biogenic irrigation intensity and solute exchange on diagenetic reaction rates in marine sediments. J. Mar. Res. 56, 905-936.

Bernhard, J.M., 1993. Experimental and field evidence of Antarctic foraminiferal tolerance to anoxia and hydrogen sulfide. Mar. Micropaleontol. 20, 203-213.

Bernhard, J.M., 1996. Microaerophilic and facultative anaerobic benthic foraminifera: a review of experimental and ultrastructural evidence. Rev. Paléobiol. 15, 261-275.

Bernhard, J.M., 2003. Potential symbionts in bathyal foraminifera. Science 299 (5608), 861.

Bernhard, J.M., Alve, E., 1996. Survival, ATP pool, and ultrastructural characterization of benthic foraminifera from Drammensfjord (Norway): response to anoxia. Mar. Micropaleontol. 28 (1), 5-17.

Bernhard, J.M., Bowser, S.S., 2008. Peroxisome proliferation in foraminifera inhabiting the chemocline: an adaptation to reactive oxygen species exposure? J. Eukaryot. Microbiol. 55, 3,135-144.

Bernhard, J.M., Edgcomb, V.P., Casciotti, K.L., McIlvin, M.R., Beaudoin, D.J., 2012 Denitrification likely catalyzed by endobionts in an allogromiid foraminifer. ISME J. 6 (5), 951-960.

Bernhard, J.M., Tsuchiya, M., Nomaki, H., 2017. Ultrastructural observations on prokaryotic associates of benthic foraminifera: food, mutualistic symbionts, or parasites? Mar. Micropaleontol. http://dx.doi.org/10.1016/j.marmicro.2017.09.001. (in press).

Bonaglia, S., Nascimento, F.J.A., Bartoli, M., Klawonn, I., Brüchert, V., 2014. Meiofauna increases bacterial denitrification in marine sediments. Nat. Commun. 5, 5133.

Cesbron, F., Geslin, E., Jorissen, F.J., Delgard, M.L., Charrieau, L., Deflandre, B., Jézéquel, D., Anschutz, P., Metzger, E., 2016. Vertical distribution and respiration rates of benthic foraminifera: contribution to aerobic remineralization in intertidal mudflats covered by Zostera noltei meadows. Estuar. Coast. Shelf Sci. 179, 23-38.

Frontalini, F., Curzi, D., Cesarini, E., Canonico, B., Giordano, F.M., De Matteis, R., Bernhard, J.M., et al., 2016. Mercury-pollution induction of intracellular lipid accumulation and lysosomal compartment amplification in the benthic foraminifer Ammonia parkinsoniana. PLoS One 11, e0162401.

Frontalini, F., Nardelli, M.P., Curzi, D., Martin-Gonzalez, A., Sabbatini, A., Negri, A., Losada, M.T., Gobbi, P., Coccioni, R., Bernhard, J.M., 2017. Benthic foraminiferal ultrastructural alteration induced by heavy metals. Mar. Micropaleontol. http://dx. doi.org/10.1016/j.marmicro.2017.10.009. (in press).

Geslin, E., Barras, C., Langlet, D., Nardelli, M.P., Kim, J.H., Bonnin, J., Metzger, E., Jorissen, F., 2014. Survival, reproduction and calcification of three benthic foraminiferal species in response to experimentally induced hypoxia. In: Kitazato, H., Bernhard, J.M. (Eds.), Experimental Approaches in Foraminifera: Collection, Maintenance and Experiments. Springer, pp. 163-195.

Gordon, G.B., Barcza, M.A., Bush, M.E., 1977. Lipid accumulation in hypoxic tissue culture cells. Am. J. Pathol. 88 (3), 663-678.

Grashoff, K., Erhardt, M., Kremling, K., 1983. Methods of Seawater Analysis. Weinheim, Verlag Chemie.

Hayward, B.W., Holzmann, M., Grenfell, H.R., Pawlowski, J., Triggs, C.M., 2004. Morphological distinction of molecular types in Ammonia - towards a taxonomic revision of the world's most commonly misidentified foraminifera. Mar. Micropaleontol. 50, 237-271.

Helder, W., 1989. Early diagenesis and sediment-water exchange in the Savu Basin (eastern Indonesia). Neth. J. Sea Res. 24, 555-572.

Holzmann, M., 2000. Species concepts in foraminifera: Ammonia as a case study. Micropaleontology 46 (Supplement 1: Advances in the Biology of Foraminifera), 21-37.

Hongguang, M., Zhiying, Y., Cadée, G.C., 1995. Macrofauna distribution and bioturbation on tidal confluences of the Dutch Wadden Sea. Neth. J. Aquat. Ecol. 29, 167-176.

Koho, K.A., Piña-Ochoa, E., Geslin, E., Risgaard-Petersen, N., 2011. Vertical migration, nitrate uptake and denitrification: survival mechanisms of foraminifers (Globobulimina turgida) under low oxygen conditions. FEMS Microbiol. Ecol. 75 (2), 273-283.

Le Cadre, V., Debenay, J.-.P., 2006. Morphological and cytological responses of Ammonia (foraminifera) to copper contamination: implication for the use of foraminifera as bioindicators of pollution. Environ. Pollut. 143 (2), 304-317.

Lee, S.-J., Zhang, J., Choi, A.M.K., Kim, H.P., 2013. Mitochondrial dysfunction induces formation of lipid droplets as a generalized response to stress. Oxidative Med. Cell. Longev. 327167.

LeKieffre, C., Spangenberg, J.E., Mabilleau, G., Escrig, S., Meibom, A., Geslin, E., 2017. Surviving anoxia in marine sediments: the metabolic response of ubiquitous benthic foraminifera (Ammonia tepida). PLoS One 2 (5), e0177604.

Linke, P., 1992. Metabolic adaptations of deep-sea benthic foraminifera to seasonally varying food input. Mar. Ecol. Prog. Ser. 81, 51-63.

Mi-ichi, F., Makiuchi, T., Furukawa, A., Sato, D., Nozaki, T., 2011. Sulfate activation in mitosomes plays an important role in the proliferation of Entamoeba histolytica. PLoS Negl. Trop. Dis. 5, e1263.

Mi-ichi, F., Miyamoto, T., Takao, S., Jeelani, G., Hashimoto, T., Hara, H., Nozaki, T., Yoshida, H., 2015. Entamoeba mitosomes play an important role in encystation by association with cholesteryl sulfate synthesis. Proc. Natl. Acad. Sci. U. S. A. E2884-E2890.

Moodley, L., Hess, C., 1992. Tolerance of infaunal benthic foraminifera for low and high oxygen concentrations. Biol. Bull. 183, 94-98.

Morvan, J., Le Cadre, V., Jorissen, F., Debenay, J.-P., 2004. Foraminifera as potential bioindicators of the "Erika" oil spill in the bay of Bourgneuf: field and experimental studies. Aquat. Living Resour. 17 (3), 317-322.

Nardelli, M.P., Barras, C., Metzger, E., Mouret, A., Filipsson, H.L., Jorissen, F., Geslin, E., 2014. Experimental evidence for foraminiferal calcification under anoxia. Biogeosciences 11 (14), 4029-4038.

Nomaki, H., Chikaraishi, Y., Tsuchiya, M., Toyofuku, T., Ohkouchi, N., Uematsu, K., Tame, A., Kitazato, H., 2014. Nitrate uptake by foraminifera and use in conjunction with endobionts under anoxic conditions. Limnol. Oceanogr. 59, 1879-1888.

Nomaki, H., Toyofuku, T., Tsuchiya, M., Matsuzaki, T., Uematsu, K., Tame, A., 2015. Three-dimensional observation of foraminiferal cytoplasmic morphology and internal structures using uranium-osmium staining and micro-X-ray computed tomography. Mar. Micropaleontol. 121, 32-40.

Nomaki, H., Bernhard, J.M., Ishida, A., Tsuchiya, M., Uematsu, K., Tame, A., Kitahashi, T., Takahata, N., Sano, Y., Toyofuku, T., 2016. Intracellular isotope localization in Ammonia sp. (foraminifera) of oxygen-depleted environments: results of nitrate and sulfate labeling experiments. Front. Microbiol. 7, 163.

Nomaki, H., LeKieffre, C., Meibom, A., Escrig, S., Yagyu, S., Richardson, E.A., Matsuzaki, T., Murayama, M., Geslin, E., Bernhard, J.M., 2017. Innovative TEM-coupled approaches to study foraminiferal cells. Mar. Micropaleontol. http://dx.doi.org/10. 
1016/j.marmicro.2017.10.002. (in press).

Nyholm, K.G., Nyholm, P.G., 1975. Ultrastructure of monothalamous Foraminifera. Zoon. 3, 141-150.

Piña-Ochoa, E., Høgslund, S., Geslin, E., Cedhagen, T., Revsbech, N.P., Nielsen, L.P., Schweizer, M., Jorissen, F., Rysgaard, S., Risgaard-Petersen, N., 2010. Widespread occurrence of nitrate storage and denitrification among foraminifera and gromiida. Proc. Natl. Acad. Sci. U. S. A. 107, 1148-1153.

Prévot, P., Soyer, M.O., 1978. Action of cadmium on a free dinoflagellate Prorocentrum micans E: growth, cadmium absorption and cell modifications. In: Comptes Rendus Hebdomadaires Des Seances De l'Academie Des Sciences. Serie D: Sciences Naturelles 287, 8. pp. 833-836.

Risgaard-Petersen, N., Langezaal, A.M., Ingvardsen, S., Schmid, M.C., Jetten, M.S.M., Op Den Camp, H.J.M., Derksen, J.W.M., et al., 2006. Evidence for complete denitrification in a benthic foraminifer. Nature 443 (7107), 93-96.

Ross, B.J., Hallock, P., 2016. Dormancy in the foraminifera: a review. J. Foraminiferal Res. 46, 358-368.

Schindelin, J., Arganda-Carreras, I., Frise, E., Kaynig, V., Longair, M., Pietzsch, T.,
Preibisch, S., Rueden, C., Saalfeld, S., Schmid, B., Tinevez, J.-Y., White, D.J., Hartenstein, V., Eliceiri, K., Tomancak, P., Cardona, A., 2012. Fiji: an open-source platform for biological-image analysis. Nat. Methods 9, 676-682.

Schweizer, M., Polovodova, I., Nikulina, A., Schönfeld, J., 2011. Molecular identification of Ammonia and Elphidium species (foraminifera, rotaliida) from the Kiel Fjord (SW Baltic Sea) with rDNA sequences. Helgol. Mar. Res. 65, 1-10.

Taillefert, M., Neuhuber, S., Bristow, G., 2007. The effect of tidal forcing on biogeochemical processes in intertidal salt marsh sediments. Geochem. Trans. 8.

Thibault De Chanvalon, A., Metzger, E., Mouret, A., Cesbron, F., Knoery, J., Rozuel, E., Launeau, P., Nardelli, M.P., Jorissen, F.J., Geslin, E., 2015. Two-dimensional distribution of living benthic foraminifera in anoxic sediment layers of an estuarine mudflat (Loire Estuary, France). Biogeosciences 12, 6219-6234.

Tsuchiya, M., Toyofuku, T., Uematsu, K., Brüchert, V., Collen, J., Yamamoto, H., et al., 2015. Cytologic and genetic characteristics of endobiotic bacteria and kleptoplasts of Virgulinella fragilis (foraminifera). J. Eukaryot. Microbiol. 62, 454-469.

Wenzhöfer, F., Glud, R.N., 2004. Small-scale spatial and temporal variability in coastal benthic $\mathrm{O}_{2}$ dynamics: effects of fauna activity. Limnol. Oceanogr. 49 (5), 1471-1481. 